Screw Consent 



\section{Screw Consent}

A Better Politics of Sexual Justice

\section{Joseph J. Fischel}

따 
University of California Press, one of the most distinguished university presses in the United States, enriches lives around the world by advancing scholarship in the humanities, social sciences, and natural sciences. Its activities are supported by the UC Press Foundation and by philanthropic contributions from individuals and institutions. For more information, visit www.ucpress.edu.

University of California Press

Oakland, California

(C) 2019 by The Regents of the University of California

Library of Congress Cataloging-in-Publication Data

Names: Fischel, Joseph J., author.

Title: Screw consent : a better politics of sexual justice / Joseph J. Fischel.

Description: Oakland, California : University of California Press, [2019] I Includes bibliographical references and index. I

Identifiers: LCCN 2018020265 (print) I LCCN 2018026660 (ebook) I ISBN 9780520968 I72 (ebook) I ISBN 9780520295407 (cloth : alk. paper) I ISBN 97805202954I4 (pbk. : alk. paper)

Subjects: LCSH: Sexual consent. I Sex-Political aspects. | Sexual ethics. I Sex and law.

Classification: LCC HQ32 (ebook) I LCC HQ32 .F573 20 I9 (print) I DDC I76/.4-dc23

LC record available at https://lccn.loc.gov/20I 8020265

Manufactured in the United States of America

$\begin{array}{llllllllll}28 & 27 & 26 & 25 & 24 & 23 & 22 & 21 & 20 & \text { I9 }\end{array}$

$\begin{array}{llllllllll}\text { IO } & 9 & 8 & 7 & 6 & 5 & 4 & 3 & 2 & \text { I }\end{array}$ 